P ISSN : 2503 - 1708

E ISSN : 2722 - 7340

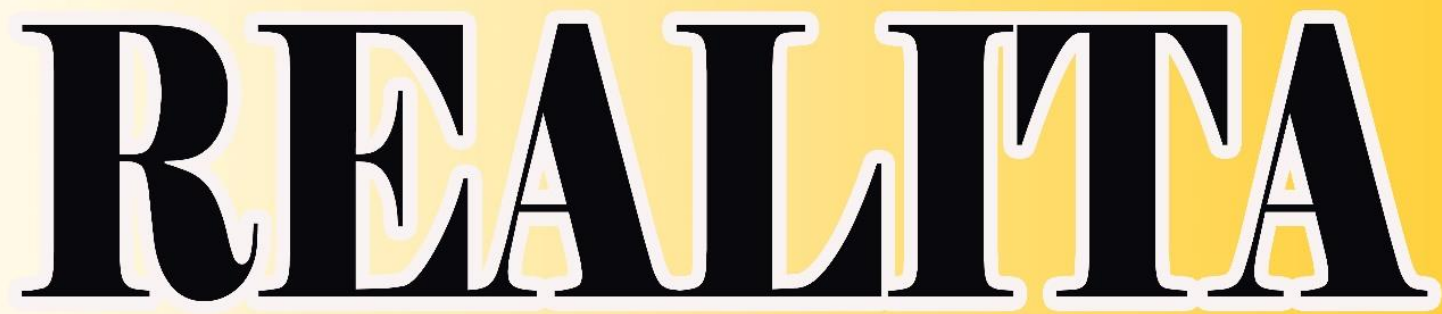

Jurnal Bimbingan dan Konseling

\begin{tabular}{|c|c|c|c|c|c|}
\hline JURNAL & VOLUME & NOMOR & EDISI & HALAMAN & P ISSN : 2503 - 1708 \\
REALITA & 6 & 2 & Oktober 2021 & $1326-1430$ & E ISSN : 2722 - 7340 \\
\hline
\end{tabular}

Diterbitkan oleh:

PROGRAM STUDI BIMBINGAN DAN KONSELING FAKULTAS ILMU PENDIDIKAN DAN PSIKOLOGI UNIVERSITAS PENDIDIKAN MANDALIKA 


\section{REALITA \\ BIMBINGAN DAN KONSELING \\ Jurnal Penelitian dan Pengembangan Pendidikan}

\section{DEWAN REDAKASI \\ Pelindung : Rektor Universitas Pendidikan Mandalika \\ : Dekan FIPP Universitas Pendidikan Mandalika \\ Penanggung \\ Jawab \\ : Kaprodi BK FIPP Universitas Pendidikan Mandalika \\ Editor}

Hariadi Ahmad, M.Pd

Universitas Pendidikan Mandalika

Associate Editor

Mustakim, M.Pd

Universitas Pendidikan Mandalika

Mujiburrahman, M.Pd

Universitas Pendidikan Mandalika

Ahmad Muzanni, M.Pd

Universitas Pendidikan Mandalika

M. Chaerul Anam, M.Pd

Universitas Pendidikan Mandalika

\section{Editorial Board}

Prof. Drs. Kusno, DEA., Ph.D

Universitas Negeri Jember Jawa Timur

Drs. Wayan Tamba, M.Pd

Farida Herna Astuti, M.Pd

Ichwanul Mustakim, M.Pd

Reza Zulaifi, M.Pd

Jessica Festi Maharani, M.Pd

Universitas Pendidikan Mandalika

Universitas Pendidikan Mandalika

Universitas Pendidikan Mandalika

Universitas Pendidikan Mandalika

Universitas Pendidikan Mandalika

\section{Reviwer}

Dr. I Made Sonny Gunawan, S.Pd., M.Pd

Universitas Pendidikan Mandalika

Dr. A. Hari Witono, M.Pd

Universitas Mataram NTB

Prof. Dr. Wayan Maba

Universitas Mahasaraswati Bali

Dr. Gunawan, M.Pd

Universitas Mataram NTB

Dr. Haromain, S.Pd., M.Pd.

Universitas Pendidikan Mandalika

Dr. Hadi Gunawan Sakti, M.Pd

Wiryo Nuryono, M.Pd

Hasrul, S.PdI., M.Pd

Dita Kurnia Sari, M.Pd

Dr. Roro Umy Badriyah. M.Pd., Kons

Universitas Pendidikan Mandalika

Universitas Negeri Surabaya Jawa Timur

STKIP Kie Raha Ternate Maluku Utara

UIN Sunan Ampel Surabaya Jawa Timur

Universitas PGRI Maha Dewa Bali

Ari Khusumadewi, M.Pd

Universitas Negeri Surabaya Jawa Timur 
M. Najamuddin, M.Pd

M. Samsul Hadi, M.Pd

Lalu Jaswandi, M.Pd

Eneng Garnika, M.Pd

Aluh Hartati, M.Pd

Drs. I Made Gunawan, M.Pd

Nuraeni, S.Pd., M.Si

Baiq Sarlita Kartiani, M.Pd

M. Zainuddin, M.Pd

Ahmad Zainul Irfan, M.Pd

Dra. Ni Ketut Alit Suarti, M.Pd

Asep Sahrudin, S.Pd., M.Pd

Suciati Rahayu Widyastuti, S.Pd., M.Pd

Rahmawati M, S.Pd., M.Pd

Ginanjar Nugraheningsih, S.Pd. Jas., M.Or

Dewi Ariani, S.Pd., M.Pd

St. Muriati, S.Pd., M.Pd

Uli Agustina Gultom, S.Pd., M.Pd

Indra Zultiar, S.Pd., M.Pd.
Universitas Pendidikan Mandalika

Universitas Pendidikan Mandalika

Universitas Pendidikan Mandalika

Universitas Pendidikan Mandalika

Universitas Pendidikan Mandalika

Universitas Pendidikan Mandalika

Universitas Pendidikan Mandalika

Universitas Pendidikan Mandalika

Universitas Pendidikan Mandalika

Universitas Pendidikan Mandalika

Universitas Pendidikan Mandalika

Univ. Mathla'ul Anwar Banten

Univ. Nahdlatul Ulama Cirebon

Universitas Muhammadiyah Kendari Sulawesi Tenggara

Universitas Mercu Buana Yogyakarta

Universitas Mahaputra Muhammad Yamin Solok Sumatera Barat

Universitas Bosowa Makassar Sulawesi Selatan

Universitas Borneo Tarakan Kalimantan Utara

Universitas Muhammadiyah Sukabumi Jawa Barat

\section{Alamat Redaksi:}

Redaksi Jurnal Realita Bimbingan dan Konseling (JRbk)

Program Studi Bimbingan dan Konseling

Fakultas Ilmu Pendidikan dan Psikologi Universitas Pendidikan Mandalika

Gedung Dwitiya, Lt. 3 Jalan Pemuda No. 59 A Mataram Telp. (0370) 638991

Email : realita@undikma.ac.id

Web : e-journal.undikma.ac.id

Jurnal Realita Bimbingan dan Konseling menerima naskah tulisan penulis yang original (belum pernah diterbitkan sebelumnya) dalam bentuk soft file, office word document (Email) atau Submission lansung di akun yang diterbitkan setiap bulan April dan Oktober setiap tahun.

Diterbitkan Oleh: Program Studi Bimbingan dan Konseling Fakultas Ilmu Pendidikan dan Psikologi Universitas Pendidikan Mandalika. 


\section{DAFTAR ISI}

Halaman

\section{Nuraeni dan Mastari}

Pengaruh Konseling Kelompok Terhadap Self Esteem Siswa Kelas XI di SMK Negeri 2 Kuripan

\section{Aprilia Yolanda, Ni Ketut Alit Suarti dan Ahmad Muzanni}

Pengaruh Body Shaming Terhadap Kepercayaan Diri Siswa SMA Negeri

1 Batulayar

$1342-1353$

\section{Hariadi Ahmad}

Hubungan Kestabilan Emosi dengan Kontrol Diri Siswa Sekolah Menegah Pertama

\section{Aluh Hartati}

Pengaruh Teknik Modeling Untuk Meningkatkan Empati Siswa

\section{Mustakim}

Pengaruh Teknik Cerita Terhadap Sikap Kemandirian Anak Pada Usia 5-6 Tahun

\section{Farida Herna Astuti dan Ichwanul Mustakim}

Keefektifan Bimbingan Kelompok dengan Teknik Role Playing untuk Meningkatkan Motivasi Belajar

\section{Mujiburrahman dan Soba Al-Qadri}

Hubungan Antara Kemampuan Kontrol Diri Dengan Penyusaian Diri Pada Siswa Kelas XI SMA Negeri 1 Taliwang

\section{Wiwiek Zainar Sri Utami}

Pengaruh Konseling Individu Terhadap Potensi Diri Anak Tunarungu di Sekolah Inklusi

\section{Baiq Nur'aini Cahya Khairani dan Ni Made Sulastri}

Pengaruh Layanan Konseling Humanistik Terhadap Perilaku Agresif pada Siswa Kelas XI IPS-4 di SMA Negeri 7 Mataram

\section{Najamudin}

Pengaruh Teknik Biblioterapi Terhadap Sikap Kemandirian Belajar Pada Siswa VIII SMP Negeri 5 Lembar

\section{Khaerul Huda}

Meningkatkan Pengetahuan dan Pemahaman Perilaku Hidup Bersih dan Sehat dimasa Covid 19 Melalui Metode Demontrasi pada Kelompok B di TK Negeri 01 Wanasaba 


\title{
PENGARUH TEKNIK MODELING UNTUK MENINGKATKAN EMPATI SISWA
}

\author{
Oleh: \\ Aluh Hartati \\ Dosen Program Studi Bimbingan dan Konseling Fakultas Ilmu Pendidikan dan \\ Psikologi Universitas Pendidikan Mandalika \\ Email: aluhhartati@undikma.ac.id
}

\begin{abstract}
Abstrak. Teknik modeling adalah teknik untuk mempelajari perilaku baru dengan mengamati model dan mempelajari keterampilannya. Teknik ini bertujuanagar siswa dapat membantu dirinya dalam pengembangan diri seperti ikut merasakan apa yang dirasakan orang lain untuk menumbuhkan rasa empati. Tujuan dari penelitian ini adalah untuk mengetahui Apakah ada pengaruh Teknik Modeling untuk meningkatkan empati siswa. Metode pengumpulan data yang digunakan adalah metode angket sebagai metode pokok dan metode observasi, wawancara serta dokumentasi sebagai metode pelengkap. Tehnik sampling yang digunakan dalam penelitian ini adalah purposive sampling. Populasi dalam penelitian ini adalah 184 siswa dan sampel yang digunakan untuk memperoleh data adalah 10 orang siswa. Untuk menganalisa data menggunakan rumus $t$-test, berdasarkan analisis data $t$ hitung sebesar 5,308 dengan nilai $t$ tabel pada taraf signifikansi $5 \%$ dengan $\mathrm{db}(\mathrm{N}-1)=9$ sebesar 2,262. Dengan demikian nilai $t$ hitung lebih besar daripada nilai $t$ pada table $(5,308>2,262)$, sehingga dapat di simpulkan Ada Pengaruh Tehnik modeling untuk meningkatkan Empati Siswa.
\end{abstract}

Kata Kunci: Teknik modeling dan Empati.

\section{PENDAHULUAN}

Pendidikan dapat dirumuskan dari sudut normatif, artinya bahwa dalam peristiwa pendidikan, pendidik (pengajar/guru) dan anak didik (siswa) berpegang pada ukuran, norma, hidup, pandangan terhadap individu dan masyarakat, nilainilai moral, kesusilaan yang semuanya merupakan sumber norma didalam pedidikan. Aspek ini sangat dominan dalam merumuskan tujuan secara umum, karena pendidikan menurut hakikatnya memang sebagai suatu peristiwa yang memiliki norma (Sardiman, 2011). Pendidikan sangat penting untuk meningkatkan kualitas sumber daya manusia khususnya bagi Indonesia sebagai negara berkembang (Aluh $\mathrm{H}$, Hariadi A dan Andika RM. 2020). Untuk mendapatkan keluaran maksimal dalam proses belajar mengajar, peran tenaga pembimbing dan siswa tidak dapat dipisahkan. Siswa harus memiliki keberanian menyampaikan pendapatnya dan kepercayaan diri yang tinggi serta memiliki tanggung jawab akan apa yang dilakukannya. Sedangkan untuk tenaga pendidik, diuraikan dalam PP No. $38 / 1998$ pasal 1 ayat 3 yang mengemukakan bahwa "tenaga pembimbing adalah tenaga pendidikan yang bertugas membimbing siswa". Pasal 3 ayat 2 mengemukakan "tenaga pendidik terdiri atas pembimbing, pengajardan pelatih". Jadi guru pembimbing adalah salah satu dari tenaga kependidikan yang mengemban sebagian tugas kependidikan di sekolah, yaitu sebagai penanggung jawab terlaksananya kegiatan bimbingan dan konseling yang mencakup dimemsidimensi kemanusiaan. Salah satu layanan bimbingan konseling yaitu bimbingan kelompok. Menurut Prayitno (2012) mewujudkan dimensi kemanusiaan dalam bimbingan kelompok yaitu melalui dinamika kelompok yang intensif, pembahasan topik-topik itu mendorong pengembangan perasaan, pikiran, persepsi, wawasan, dan sikap yang 
menunjang diwujudkan tingkah laku yang lebih efektif dan bertanggung jawab. Sedangkan menurut Neviyarni (2009) dalam bimbingan kelompok siswa yang mampu mewujudkan diri, akan mampu berdiri sendiri sebagai pribadi yang mantap dan mandiri serta memiliki sifat-sifat yang positif dan rasa empati kepada orang lain (Hariadi A dan Aluh H. 2016)

Empati merupakan dasar dari kecerdasan moral. Kebijakan moral yang pertama ini mengasah kepekaan individu terhadap perbedaan sudut pandang dan pendapat orang lain. Empati berperan meningkatkan sifat kemanusiaan, keadaban dan moralitas. Empati merupakan emosi yang mengusik hati nurani siswa ketika melihat kesusahan orang lain. Hal tersebut juga membuat siswa menunjukkan toleransi dan kasih sayang, memahami kebutuhan orang lain, serta mau membantu orang lain yang sedang dalam kesulitan. Siswa yang belajar empati akan jauh lebih pengertian dan penuh kepedulian serta lebih mampu mengendalikan kemarahan (Hariadi A dan Aluh H. 2016). Rogers dalam (Paderson, 2008) menyatakan "empathy as the ability to perceive the internal frame of reference of another with accuracy and with the emotional component and meaning with pertain thereto as if one were the person without ever losing the as if condition" Artinya: "Empati adalah kemampuan untuk memahami kondisi atau keadaan pikiran orang lain dengan tepat, dan tanpa kehilangan kondisi nyata. Seorang yang empati digambarkan sebagai seorang yang toleran, mampu mengendalikan diri, ramah, mempunyai pengaruh serta bersifat humanistic". Menurut Ibrahim (2003) mengatakan empati adalah "menyelaraskan diri" (Peka) terhadap apa, bagaimana dan latar belakang perasaan dan pikiran orang lain sebagaimana orang tersebut merasakan dan memikirkannya.
Sedangkan empati memiliki sejumlah komponen. Menurut Taufik (2012) Komponen empati terdiri dari komponen kognitif, komponen afektif dan komponen komunikatif. Sedangkan Menurut Davis (1983) secara global ada dua komponen dalam empati, yaitu komponen afektif yang masing-masing mempunyai dua spek, yaitu perspektif taking dan fantacy, sedangkan komponen afektif meliputi Emphatic Concern dan Personal Distress. Menurut Carl Rogers (Taufik, 2012) menyebutkan bahwa" sikap empati adalah suatu proses di mana seseorang berpikir mengenai kondisi orang lain yang seakan akan dia berada pada posisi orang lain itu sehingga bisa merasakan dan mengalami sebagaimana yang dirasakan dan dialami orang lain itu, tetapi tanpa kehilangan identitas dirinya sendiri". Sikap empati membuat seseorang menjadi tahu bagaimana kondisi psikologis orang lain, sehingga seseorang dapat memahami apa yang sedang dipikirkan dan dirasakannya. Pemahaman ini akan menjadi tali perekat dalam hubungan sosial, dan meningkatkan kualitas hubungan (Hariadi A dan Dini K. 2017).

Empati adalah merasakan sesuatu bentuk atau perasaan tertentu seperti apa yang dirasakan atau dideritakan oleh orang lain. beda halnya dengan simpati yang menimbulkan ketertarikan semata tetapi tidak adanya sesuatu tindakan ataupun ketertarikan secara emosional. Kemampuan mengindera perasaan seseorang sebelum yang bersangkutan mengatakannya merupakan intisari empati. Tanpa kemampuan ini orang dapat menjadi terasing, salah menafsirkan perasaan yang berakibat rusaknya hubungan. Salah satu wujud empati adalah ketika seseorang cenderung menyamaratakan orang lain dengan dirinya (Hariadi A, Ahmad ZI dan Dedi A. 2020).

Dari berbagai definisi di atas dapat disimpulkan bahwa empati 
merupakan suatu kemampuan untuk memahami apa yang sedang dipikirkan dan dirasakan orang lain, yang dapat dikomunikasikan secara verbal maupun nonverbal tanpa yang bersangkutan kehilangan kontrol dirinya, sehingga seseorang tersebut tidak hanyut dalam suasana orang lain. Siswa yang memiliki empati dapat bergaul dan bersosialisasi dengan orang lain dengan baik, dapat menyesuaikan diri dengan lingkungan di sekitarnya dan dapat diterima oleh lingkungan dimanapun individu itu berada (Hariadi A, Aluh $\mathrm{H}$ dan Jessica FM. 2020).

Untuk meningkatkan sikap empati di sekolah pada pendidik khusunya guru BK (Bimbingan dan Konseling) memiliki peran yang sangat besar untuk membina, siswa-siswanya menjadi generasi yang memiliki empati yang tinggi, seperti yang sering kali guru BK lakukan ialah memberikan suatu bimbingan atau proses belajar mengajar dengan menggunakan metode modeling. Bimbingan konseling memiliki berbagai pendekatan dan teknik yang dapat digunakan untuk membantu siswa meraih pengembangan diri yang optimal sesuai dengan tahap perkembangan dan tuntutan lingkungan sekitarnya. Salah satu teknik yang dapat digunakan yaitu teknik modeling (Hariadi A, Aluh $\mathrm{H}$, dan Nuraeni. 2018). Ada beberapa pengertian modeling menurut para ahli. Teknik modeling adalah teknik konseling dalam pendekatan behavioral yang berakar dari teori Albert Bandura dalam teori belajar sosial, yaitu teknik untuk merubah, menambah maupun mengurangi tingkah laku individu dengan belajar melalui observasi langsung (observational learning) untuk meniru perilaku orang maupun tokoh yang ditiru (model) sehingga individu memperoleh tingkah laku baru yang diinginkan (Shaleh, 2004). Teknik modelling adalah yang bertujuan untuk mempelajari perilaku baru dengan mengamati model dan mempelajari

keterampilannya (Hutomono, 2011).

Bandura 1986 (Corey 2005) menegaskan peranan pemodelan dalam pengembangan dan modifikasi banyak dari perilaku manusia. Terdapat beberapa tipe model dalam modeling. Model yang dapat digunakan untuk belajar tingkah laku adalah live model yang terdiri dari mastery model dan coping model, symbolik model, dan multiple model. Berdasarkan pendapat para ahli diatas dapat disimpulkan bahwa Teknik modelling adalahteknik untuk merubah, menambah maupun mengurangi tingkah laku individu dengan belajar melalui observasi langsungyang bertujuan untuk mempelajari perilaku baru dengan mengamati model dan mempelajari keterampilannya. Berdasarkan hasil observasi awal pada penelitian yang dilakukan di beberapa SMA di Kabupaten Lombok Barat ditemukan sejumlah masalah pada peserta didik seperti: jika ada teman yang tidak memiliki polpen saat ujian di kelas mereka tidak membantu untuk meminjamkan polpen ke temanya, jika ada teman yang tidak masuk sekolah karena sakit mereka tidak mau menjenguk ke rumahnya, jika ada teman yang tidak mengerti tentang tugas yang di berikan guru, teman sekelasnya tidak mau membantu teman yang tidak megerti tentang tugas yang di berikan guru di kelas, jika ada salah satu siswa yang tidak membawa buku catatan untuk belajar teman sekelasnya tidak mau meminjamkan buku catatannya, jika ada salah satu teman yang tidak memiliki kendaraan pada saat pulang sekolah siswa yang lain tidak mau memberikan tumpangan ke temannya yang tidak ada kendaraan. Adapun penyebab masalah itu muncul di karnakan orang tua yang tidak berempati dengan lingkungan atau keadaan sekitarnya, didikan kepada anak selalu di dekte, jika ada kegiatan gotong royong masjid orang tua tidak ikut serta 
dalam kegiatan tersebut, jika ada kegiatan remaja masjid anak tidak didorong untuk ikut dalam kegiatan tersebut, jika ada tetangga yang sedang sakit orang tua tidak mau menjenguknya, tidak pernah mau bergabung pada saat ada kegiatan kepemudaan di lingkunganya.

Adapun faktor yang mempengaruhi masalah itu muncul: 1) faktor internal yang berasal dari siswa itu sendiri atau dari keluarga itu sendiri. Seperti sulit bergaul dengan keluarga dan anak broken home. 2). Faktor eksternal dari lingkungan seperti orang tua yang kurang peduli terhadap anaknya sehingga menyebabkan anak tersebut tidak memiki sikap empati dan lingkungan tempat bergaul dengan teman sebayanya dengan mayoritas kurang peduli dengan masalah oran lain. Berdasarkan masalah diatas, maka peneliti berpendapat bahwa orang tua mempunyai peran yang sangat penting, dimana orang tua diharapkan dapat menjadi model dalam meningkatkan empati pada anak, dan peran guru juga sangat diharapkan bisa menjadi model dalam proses pembelajaran terutama dalam sikap empati siswa.

\section{KAJIAN PUSTAKA}

Teknik modeling adalah teknik konseling dalam pendekatan behavioral yang berakar dari teori Albert Bandura dalam teori belajar sosial, yaitu teknik untuk merubah, menambah maupun mengurangi tingkah laku individu dengan belajar melalui observasi langsung (observational learning) untuk meniru perilaku orang maupun tokoh yang ditiru (model) sehingga individu memperoleh tingkah laku baru yang diinginkan (Shaleh, 2004). Teknik modelingbertujuan untuk mempelajari perilaku baru dengan mengamati model dan mempelajari keterampilannya (Hutomono, 2011).
Menurut Komalasari (2010) langkah-langkah teknik modeling adalah sebagai berikut: a). Menetapkan bentuk modeling yang akan dipakai (live model, symbolic model, dll), b) Untuk live model, piliha teman yang merupakan sahabat dekat atau teman sebaya konseli yang memiliki kesamaan seperti usia, status ekonomi, dan penampilan fisik. Hal ini sangat penting terutama bagi anak-anak, c) Bila mungkin, akan lebih baik untuk menggunakan lebih dari satu model, d) Kompleksitas perilaku yang di jadikan model harus sesuai dengan tingkat perilaku konseli, e) Kombinasikan modeling dengan aturan, instruksi, behavioral rehearsal, dan penguatan, f) Pada saat konseli memperhatikan penampilan tokoh, berikan penguatan alamiah kepada konseli, g) Bila mungkin, buat desain pelatihan untuk konseli menirukan model secara tepat, sehingga akan mengarahkan konseli pada penguatan alamiah. Bila tidak maka buat perencanaan pemberian penguatan untuk setiap peniruan tingkah laku yang tepat, h) Bila perilaku bersifat kompleks, maka episode modeling dilakukan mulai dari yang paling mudah ke yang lebih sukar, i) Skenario modeling harus dibuat realistic, j) Melakukan pemodelan dimana tokoh menunjukan perilaku yang menimbulkan rasa takut bagi konseli (dengan sikap manis, perhatian, bahasa yang lembut, dan perilaku yang menyenangkan konseli). (Hariadi A, dan Andry AM. 2019).

Teknik modeling yang digunakan dalam penelitian ini berkaitan dengan peniruan atau mencontoh. Menurut Zakarias Sukarya (2010) mengatakan bahwa secara teori penerimaan teknik modelling ini didasarkan pada beberapa hal yaitu: Secara naluri, siswa belajar dengan cara mencontoh, Mencontoh merupakan pekerjaan mudah serta ringan, Dapat mempertajam pengamatan, Model yang dicontoh pada umumnya 
dalam keadaan diam. Dengan demikian latihan dapat menjadi efektif untuk tujuan meniru benda yang dimaksud. Dengan demikian teknik modeling merupakan salah satu teknik di mana seseorang belajar membuat sesuatu melalui proses pengamatan, mengobservasi model, di mana dalam modeling ini juga melibatkan proses kognitif dan kreatif bukan semata- mata meniruimitasi saja. (Hariadi A, dan Yolana O. 2019)

Kelebihan metode modeling menurut Zakarias Sukarya (2010) diataranya; Memudahkan siswa untuk menyerap materi pembelajaran, Kegiatan pembelajaran akan dirancang melalui pengamatan melibatkan proses modelling dan imitation karena sesuai dengan karakteristik perkembangan emosi, adaptasi sosial dan mental anak, Pada proses pembelajaran siswa diberi kebebasan untuk berkreasi namun tetap sesuai dengan model yang diperagakan, Pemberian motivasi berupa nilai, pujian, atau hadiah akan memunculkan motivasi tersendiri bagi siswa. Siswa yang belum memperoleh penguatan akan termotivasi ingin mendapatkan penguatan seperti yang diperoleh temannya. Penguatan yang diterima akan mengakibatkan aktivitas siswa meningkat (Hariadi A, Mustakim dan Syafaruddin. 2018).

Menurut Sadmoko (2010) adapun penerapan teknik modeling dalam Bimbingan Kelompok yaitu: Attention, Perlu adanya perhatian yang dipersiapkan lebih dulu, jika model kurang menarik perhatian, tidak disukai, atau klien/individu sedang mengantuk, lapar dan tidak nyaman, proses modeling terganggu karena lemahnya perhatian. Retention, Kita perlu menyimpan informasi dalam ingatan dengan lebih dulu memberikan tanda dalam bentuk gambar atau bahasa sebagai bagian perilaku kita. Reproduction, Kemampuan mengingat kembali dan memanggil materi ingatan dari dan menterjemahkannya dalam perilaku yang nyata. Dimulai dengan membayangkan perilaku model yang kita lakukan sendiri dalam bayangan kita yang kemudian akan membantu kita menerapkannya dalam perilaku nyata. Motivation, Dorongan dari dalam individu dapat dipengaruhi oleh reinforcement yang dulu pernah diperoleh setelah melakukan perilaku tertentu (past reinforcement), reinforcement yang dijanjikan misal insentif (promised reinforcements) dalam bayangan kita dan karena melihat dan mengingat reinforce yang telah diterima model (vicarious reinforcement). Menurut Bandura, punishment tidak bekerja dengan baik dan seefektif reward dalam modeling ini.

Carl Rogers (dalam Taufik, 2012) menyebutkan bahwa" sikap empati adalah suatu proses dimana seseorang berpikir mengenai kondisi orang lain yang seakanakan dia berada pada posisi orang lain itu sehingga bisa merasakan dan mengalami sebagaimana yang dirasakan dan dialami orang lain itu, tetapi tanpa kehilangan identitas dirinya sendiri”. Sikap empati membuat seseorang menjadi tahu bagaimana kondisi psikologis orang lain, sehingga seseorang dapat memahami apa yang sedang dipikirkan dan dirasakannya. Pemahaman ini akan menjadi tali perekat dalam hubungan sosial, dan meningkatkan kualitas hubungan. Menurut Eisenberg dalam proses individu berempati melibatkan aspek afektif dan kognitif. Aspek afekif merupakan kecenderungan seseorang untuk mengalami perasaan emosional orang lain yaitu ikut merasakan ketika orang lain merasa sedih, menangis, terluka, menderita bahkan disakiti sedangkan aspek kognitif dalam empati difokuskan pada proses intelektual untuk memahami perspektif orang lain dengan tepat dan menerima pandangan mereka, misalnya membayangkan perasaan orang lain ketika marah, kecewa, senang, 
memahami keadaan orang lain dari cara berbicara, dari raut wajah dan cara pandang dalam berpendapat.

Berdasarkan pendapat para ahli diatas dapat disimpulkan bahwa empati merupakan suatu kemampuan untuk memahami apa yang sedang dipikirkan dan dirasakan orang lain, yang dapat dikomunikasikan secara verbal maupun nonverbal tanpa yang bersangkutan kehilangan kontrol dirinya, sehingga seseorang tersebut tidak hanyut dalam suasana orang lain. Siswa yang memiliki empati dapat bergaul dan bersosialisasi dengan orang lain dengan baik, dapat menyesuaikan diri dengan lingkungan di sekitarnya dan dapat diterima oleh lingkungan dimanapun individu itu berada.

Empati adalah kemampuan untuk menempatkan diri sendiri dalam keadaan psikologis orang lain dan untuk melihat suatu situasi dari sudut pandang orang lain, (Ibrahim, 2003) mengatakan empati adalah "menyelaraskan diri" (peka) terhadap apa, bagaimana dan latar belakang perasaan dan pikiran orang lain sebagaimana orang tersebut merasakan dan memikirkannya. (Decety \& Meyer, 2008) menyatakan bahwa empati adalah rasa kesamaan perasaan yang dialami oleh diri dan orang lain, tanpa kebingungan antara satu dengan yang lain. Menurut (Zuchdi, 2003), empati terdiri atas perpaduan tiga komponen, yakni: Pemahaman terhadap orang lain dengan sensitif dan tepat, namun tetap menjaga keterpisahan dari orang lain tersebut. Pemahaman keadaan yang mendorong munculnya perasaan tersebut. Cara berkomunikasi dengan orang lain yang membuat orang lain merasa diterima dan dipahami.

Davis dalam (Nashori, 2008) menjelaskan empat aspek empati antara lain, yaitu: Perspective taking, yaitu kecenderungan seseorang untuk mengambil sudut pandang orang lain secara spontan. Fantasy, yaitu kemampuan seseorang untuk mengubah diri mereka secara imajinatif dalam mengalami perasaan dan tidankan dari karakter khayal dalam buku, film, dan sandiwara yang dibaca atau ditonton. Empathic concern, yaitu perasaan simpati yang berorientasi kepada orang lain dan perhatian terhadap kemalangan yang dialami orang lain. Personal distress, yaitu kecemasan pribadi yang berorientasi pada diri sendiri serta kegelisahan dalam menghadapi setting interpersonal tidak menyenangkan. Personal distress bisa disebut empati negatif (negative empathic).

Pada akhir masa kanak-kanak, tingkat empati paling akhir muncul ketika anak-anak sudah sanggup memahami kesulitan yang ada dibalik situasi yang tampak dan menyadari bahwa situasi atau status seseorang dalam kehidupan dapat menjadi sumber beban stres kronis. Pada tahap ini, mereka dapat merasakan kesengsaraan suatu golongan, misalnya kaum miskin, kaum tertindas, mereka yang terkucil dari masyarakat. Pemahaman itu, dalam masa remaja dapat mendorong keyakinan moral yang berpusat pada kemauan untuk meringankan ketidakberuntungan dan ketidakadilan (Sudirman, 2002). Perasaan positif, seperti empati memberikan kontribusi pada perkembangan moral remaja. Walaupun empati dianggap sebagai keadaan emosional, sering kali empati memiliki komponen kognitif yaitu kemampuan melihat keadaan psikologis dalam diri orang lain, atau yang disebut dengan mengambil perspektif orang lain. Pada usia 10 sampai 12 tahun, individu membentuk empati terhadap orang lain yang hidup dalam kondisi yang tidak menguntungkan contohnya orang miskin, orang cacat dan orang-orang yang dikucilkan. Kepekaan ini membantu anak-anak yang lebih tua untuk bertingkah laku altruistik dan pada akhirnya memunculkan rasa 
kemanusiaan pada perkembangan pandangan ideologis dan politik pada remaja (Sudirman, 2002).

Adanya empati memungkinkan seseorang dapat memotivasi orang lain sehingga dapat bekerja dengan baik. Setiap orang dapat meningkatkan kepekaan perasaan sehingga memiliki tenggang rasa yang tinggi, yakni dengan membayangkan suatu keadaan dilihat dari sudut pandang orang lain. Dengan jalan demikian orang akan menjadi lebih peka terhadap reaksi orang lain, dapat merasakan apa yang dirasakan oleh orang lain, akibat selanjutnya orang tersebut dapat lebih memahami orang lain dan dapat memotivasinya untuk melakukan yang terbaik (Zuchdi, 2003). (Zuchdi, 2003) mengemukakan empati adalah kemampuan untuk menempatkan diri sendiri dalam keadaan psikologis orang lain dan untuk melihat suatu situasi dari sudut pandang orang lain. (Gazda dkk,1991) mengemukakan bahwa empati adalah tidak hanya dilakukan dalam bentuk memahami perasaan orang lain semata tetapi harus dinyatakan secara verbal dan dalam bentuk tingkah laku, mendengarkan dengan seksama, menyusun kata-kata yang sesuai untuk menggambarkan perasaan, mengenali orang lain dan berusaha memahami perasaan serta situasinya.

Menurut (Saraswati, 2008) dengan empati yaitu pengalaman menempatkan diri pada keadaan emosi orang lain seolah-olah mengalaminya sendiri. Empati inilah yang menurut Saraswati akan mendorong orang untuk melakukanpertolongan altruistis. Untuk menguji pandangan altruistik dari perilaku menolong, (Margono, 2005) merancang prosedur penelitian di mana individu meningkatkan empati bystander dengan menggambarkan dirinya sebagai salah satunya, mirip atau tidak mirip dengan korban. Bystander kemudian dihadapkan pada suatu kesempatan untuk menolong. Setiap mahasiswa partisipan penelitian diberikan peran sebagai "observer" yang melihat "teman mahasiswa" dalam monitor televisi ketika mahasiswa partisipan melakukan suatu tugas selagi (kelihatannya) menerima kejutan listrik secara acak. Teman mahasiswa ini sebenarnya asisten peneliti yang direkam pada video. Setelah tugas dilaksanakan, asisten itu berkata bahwa asisten kesakitan dan mengaku bahwa saat anak-anak dahulu mempunyai pengalaman traumatik dengan listrik. Asisten menyetujui untuk melanjutkan jika dibutuhkan tetapi peneliti bertanya apakah observer bersedia berganti tempat dengannya atau mereka harus menghentikan eksperimen tersebut. Ketika empati kurang (korban dan partisipan tidak mirip), partisipan memilih untuk mengakhiri eksperimen daripada terlibat dalam tingkah laku prososial yang menyakitkan. Ketika empati tinggi (korban dan partisipan mirip), partisipan setuju untuk menggantikan korban dan menerima kejutan listrik. Tampak bahwa tindakan altruistik ini dimotivasi hanya oleh perasaan empatik untuk korban (Hasrul dan Hariadi A. 2021).

\section{METODE PENELITIAN}

Metode adalah suatu teknik yang digunakan dalam rangka mengadakan pendekatan terhadap masalah yang diteliti. Hal ini sesuai dengan pendapat ahli yang menyatakan bahwa "Metode adalah metode atau cara yang dipakai mengadakan penelitian" (Arikunto, 2006). Sehubungan dengan hal tersebut, maka dalam buku statistik Inferensial dijelaskan bahwa "Metode penelitian dibedakan menjadi yaitu 1) Metode Empiris, dan 2) Metode Eksperimen" (Sugiyono, 2013) lebih lanjut dalam buku metodologi penelitian dijelaskan bahwa:"metode eksperimen adalah satu pendekatan dimana situasi atau gejala dibuat dengan disengaja (Arikunto, 2006). Sedangkan yang dimaksud dengan 
"Metode empiris adalah suatu pendekatan dimana gejala yang diteliti tidak dibuatkan dengan disengaja" (Sugiyono, 2013). Rancangan penelitian adalah suatu pendekatan yang digunakan dalam suatu penelitian. Dalam metodologi penelitian di jelaskanbahwa: "Rancangan pada dasarnya merupakan keseluruhan proses pemikiran dan penentuan matang tentang hal-hal yang dilakukan serta dapat pula dijadikan dasar-dasar penelitian baik oleh peneliti sendiri maupun orang lain terhadap penelitian dan bertujuan memberi pertanggung jawaban terhadap semua langkah yang diambil" (Sugiyono, 2013). Penelitian ini menggunakan desain penelitian one group pree test dan post test design dimana dalam rancangan ini hanya terdapat satu kelompok subyek yaitu kelompok eksperimen sebagai kelompok yang dikenakan perlakuan (Treatment). Pertama-tama dilakukan pengukuran terhadap kelompok eksperimen, lalu dikenakan perlakuan (Treatment) berupa layanan. Bimbingan Kelompok dalam jangka waktu tertentu, kemudian dilakukan pengukuran untuk kedua kalinya dengan tujuan untuk mengetahui perbedaan hasil pree test sebelum diberikan perlakuan (Treatment) dengan post test setelah diberikan perlakuan (Treatment).

Tehnik sampling yang digunakan dalam penelitian ini adalah tehnik Purposive Sampling. Menurut Sugiyono, (2013) Purposive Sampling adalah suatu pengambilan sampel dengan pertimbangan tertentu, serta berdasarkan ciri atau sifat tertentu yang sudah diketahui sebelumnya. Maka dalam penelitian ini ketika meneliti tentang sikap empati siswa secara otomatis yang dijadikan subjek penelitian adalah siswa yang memilik sikap empati rendah. Untuk mendapatkan siswa yang memeliki sikap empati rendah diperoleh dari hasil angket pree-test. Di dalam pelaksanaan penelitian dimulai dengan menyusun instrumen penelitian yaitu alat untuk memperoleh data yang diinginkan. Dalam penelitian ini akan menggunakan angket sebagai instrumen penelitian. Dimana penulis membuat sejumlah pertanyaan yang akan disebarkan kepada semua responden untuk dijawab. Adapun data yang harus digali untuk menjawab rumus masalah yang ada dalam penelitian ini. Dalam memperoleh data yang dibutuhkan, perlu teknik atau metode pengumpulan data, sehingga data yang diperoleh dapat dipertanggung jawabkan secara ilmiah. Teknik pengumpulan data yang dipergunakan dalam penelitian ini adalah teknik angket (Quesioner), observasi dan dokumentasi.

Sebelum dilakukan analisis data terlebih dahulu dilakukan pengumpulan data dan penelitian dilokasi yaitu data yang diperoleh dari angket, kemudian ditabulasikan sebagai bahan untuk melakukan analisis data. Analisis yang digunakan oleh peneliti adalah teknik statistik, agar lebih memperjelaskan pokok pembahasan, maka terlebih dahulu perlu dikemukakan pengertian teknik statistik. Terkait dengan penelitian ini maka metode analisis data yang digunakan adalah analisis data t-test indevendent dengan rumus pendek (shot method).

\section{HASIL PENELITIAN DAN PEMBAHASAN}

Penyusunan instrumen penelitian bertujuan untuk mempermudah penelitian dalam memperoleh data yang diperlukan dalam pelaksanaan penelitian Instrumen yang digunakan dalam penelitian ini adalah angket sebagai metode pokok yang didukung oleh metode wawancara, observasi dan dokumentasi sebagai metode pelengkap, bentuk pertanyaan di dalam angket ini adalah positif, pemberian skor adalah untuk pilihan (a) Ya diberi skor 3, (b) sering diberi skor 2, (c) kadang-kadang diberi skor. Bertitik tolak dari tujuan 
penelitian yakni, untuk mengatahui ada tidaknya Pengaruh Teknik modeling untuk meningkatkan Empati maka proses pelaksanaan penelitian ini dimulai dari penyebaran angket pre-test yang dilakukan kepada 10 orang siswa dan kemudian perlakuan/treatment. Setelah itu menyebarkan angket post-test kepada 10 orang siswa yang menjadi sampel penelitian.

Penelitian ini, data yang diperoleh melalui angket dianalisis dengan menggunakan rumus t-test, akan tetapi sebelum data-data tersebut dianalisis menggunakan rumus statistik t-test, peneliti terlebih dahulu melakukan tabulasi atas jawaban angket yang sudah terkumpul. Berdasarkan hasil perhitungan $t$-test yang diperoleh melalui analisis, ternyata nilai $\mathrm{t}$ diperoleh $=5,308$ kemudian dikonsultasikan dengan nilai $\mathrm{t}$ dalam tabel dengan $\mathrm{db}(\mathrm{N}-1)=10-1=9$ dengan taraf signifikansi $5 \%=2,262$ Penelitian ini terdiri dari dua variabel yaitu variabel bebas (indevendent variabel) dan variabel terikat (devendent variabel). Variabel bebas disini adalah teknik modeling dan variabel terikatnya adalah Empati siswa. Kedua variabel tersebut ingin diperoleh data tentang pengaruh tehnik Modeling untuk meningkatkan Empati siswa. Masingmasing variabel dalam penelitian ini dikembangkan dari berbagai literatur yang mendukung. Variabel bebas yaitu Modelingsebagai layanan untuk diberikan perlakukan (Treatment) terdiri dari empat teknik yaitu:

TeknikAttention, 2) teknikRetantion, 3) teknikReproduction dan 4) teknik Motivation. Sedangkan Empati siswa terdiri dari: 1) Perspective taking, 2) Fantasy, 3) Empathic concern, dan 4) Personal distress, yang akan dikembangkan sebagai instrument penelitian berupa angket.

Dalam penelitian tentang pengaruh tehnik modeling untuk meningkatkan Empati siswa digunakan desain eksperimen one group pretest dan post test design. Dimana dalam rancangan ini digunakan satu kelompok subyek yaitu kelompok eksperimen sebagai kelompok yang diberikan perlakuan (Treatment) sehingga dapat diketahui perbedaan hasil pree test sebelum diberikan perlakuan dan post test setelah diberikan perlakuan dengan menggunakan analisis statistik uji $\mathrm{t}$ independent. Dengan demikian, bahwa pelaksanaan teknik modeling mempunyai peranan yang positif dalam membantu Siswa meningkatkan sikap empati. Oleh karenanya kepada pihak yang terkait dalam pelaksanaan Teknik modeling ini seperti guru BK, hendaknya tetap melaksanakan teknik modelingdan melakukan kerjasama yang baik serta di lakukan secara intensif dan terprogram, karena terbukti bahwa teknik modeling akan membantu siswa dalam meningkatkan sikap empati, hal ini bisa dilihat pada hasil jawaban angket posttest siswa sebagai bukti telah melaksanakan teknik modeling, juga kepada siswa sebagai subyek pelaku, hendaknya betul-betul memanfaatkan proses teknik modeling yang ada di sekolah, serta memiliki konsep-konsep sikap positif yang berguna dalam kehidupan sehari-hari sebagai makhluk sosial, selain itu pula kepada Guru Bk, hendaknya selalu menjalin kerjasama yang baik dengan orang tua/wali murid, guru pembimbing, guru bidang studi, wali kelas serta pihak-pihak lainnya.

Dalam rangka membantu dalam meningkatkan empati siswa dan yang tidak kalah penting juga adalah orang tua/wali murid, hendaknya terus mendorong dan mengarahkan anakanaknya dengan sebaik-baiknya dalam peroses pembelajaran yang berlangsung di sekolah, sehingga mereka akan dapat diterima oleh lingkungannya, baik lingkungan keluarga, sekolah maupun lingkungan masyarakat sekitarnya yang 
pada akhirnya akan mendatangkan perubahan sikap, sehingga ia akan mendapatkan prestasi yang baik atau memuaskan di dalam bidang pendidikan. Pelaksanaan teknik modeling sangat berguna untuk meningkatkan empati siswa untuk membentuk menjadi pribadi yang baik dalam peroses pembelajaran karena siswa lebih paham tentang hal-hal yang memang seharusnya dilakukan siswa termotivasi untuk belajar, mendidik siswa lebih baik, mengubah sikap siswa lebih baik, siswa mempunyai pengetahuan baru dan siswa berkeinginan lebih baik dari sebelumnya. Selain itu dengan teknik modeling yang dilakukan akan memperbaiki dirinya dan memperbaiki sikap siswa yang dulunya kurang baik menjadi lebih baik.

Analisa yang sudah peneliti lihat selama penelitian berlangsung bahwa sebelum dilakukan teknik modeling, siswa sangat enggan dan sering merasakan malas, tidak menyukai pelajaran yang sedang berlangsung di kelas, bahkan siswa tidak menyukai guru mata pelajaran tertentu sehingga siswa merasa malas untuk mengikuti pelajaran yang sedang berlangsung di dalam kelas, tapi setelah peneliti melakukan teknik modeling dan menjelaskan secara terperinci tujuan dan pemahaman tentang teknik modeling ini, siswa tidak lagi merasa malas dan bahkan berlahan siswa mulai belajar untuk menyukai mata pelajaran tertentu dan sikap tidak senang terhadap guru mata pelajaran tertentu sedikit demi sedikit sikap mereka berubah menjadi senang terhadap gurunya dan mampu berusaha merubah diri menjadi lebih baik tentunya.

Modeling adalah suatu model penguasaan bahan-bahan pembelajaran melalui pengembangan imajinasi dan penghayatan siswa. Pengembangan imajinasi dan penghayatan dilakukan siswa dengan memerankannya sebagai tokoh hidup atau benda mati. Permainan ini pada umumnya dilakukan lebih dari satu orang, hal itu bergantung kepada apa yang di perankan, (Komalasari, 2010: 80). Melalui bimbingan kelompok yang menekankan pada tehnik modeling melibatkan seluruh siswa dimana siswa dapat berpartisispasi dan mempunyai kesempatan untuk memajukan kemampuannya dalam bekerja sama, mencoba mengeksplorasi hubungan antar manusia dengan cara memperagakannya dan mendiskusikannya sehingga secara bersama-sama para peserta didik dapat mengeksplorasi perasaan, sikap, nilai, dan berbagai strategi pemecahan masalah salah satunya seperti sikap empati siswa.

Pada dasarnya setiap anak sudah memiliki kepekaan (empati) dalam dirinya, tergantung bagaimana cara anak dan juga orangtuanya mengasah kemampuan anak tersebut. Oleh karena itu, orangtua ataupun guru sangat disarankan untuk menanamkan sifat empati kepada anak sejak dini. Eisenberg (2002: 993-1006.) menyatakan bahwa tiadanya attunement (penyesuaian diri) dalam jangka panjang antara orangtua dengan anak akan menimbulkan kerugian emosional yang sangat besar bagi anak tersebut. Apabila orang tua terus menerus gagal memperlihatkan empati apa pun dalam bentuk emosi tertentu (kebahagiaan, kesedihan, kebutuhan membelai) pada anak, maka anak akan mulai menghindar untuk mengungkapkannya. Berdasarkan landasan teori yang telah diajukan, dibandingkan dengan analisis data yang diperoleh melalui penelitian dengan menggunakan analisis statistik dengan rumus $t$-test, ternyata hipotesis nol $(\mathrm{H} 0)$ yang berbunyi: Tidak Ada Pengaruh Teknik Modeling untuk meningkatkan Empati Siswa ditolak, dan hipotesis alternatif (Ha) yang berbunyi: Ada Pengaruh Teknik Modeling untuk meningkatkan Empati Siswa diterima.

\section{KESIMPULAN DAN SARAN}


Nilai t hitung sebesar 5,308 dan nilai $t$ tabel pada taraf signifikan $5 \%$ dengan $\mathrm{N}=$ 10 , lebih besar dari pada nilai $t_{\text {test }}$ pada $t_{\text {tabel }}(5,308>2,262)$ sehingga dapat di katakan "signifikan", maka dapat di simpulkan bahwa: Ada Pengaruh Teknik modeling untuk meningkatkan Empati Siswa.

Berdasarkan simpulan di atas, peneliti sarankan kepada: Kepala Sekolah, hendaknya sebagai bahan pengambilan kebijakan untuk lebih mensosialisasikan bahwa pentingnya pelaksanaan Teknik Modeling untuk meningkatkan empati siswa supaya kreatif dan cepat tanggap untuk mengadakan teknik modeling untuk membantu dalam proses meningkatkan empati siswa. Kepada guru BK, hendaknya pelaksanaan teknik modeling dilakukan secara intensif dan terprogram, karena terbukti bahwa modelingakan membantu alam meningkatkan meningkatkan empati siswa. Kepada peneliti lain, diharapkan kepada peneliti lain yang berminat meneliti kembali tentang empati, agar mengadakan penelitian yang lebih mendalam dan lebih luas khususnya mengenai aspekaspek empati yang belum terungkap dalam penelitian ini.

\section{DAFTAR PUSTAKA}

Aluh Hartati, Hariadi Ahmad dan Andika Rifzar Mandasingi. 2020. Hubungan antara Pengendalian Diri dengan Prestasi Siswa SMKN 1 Sumbawa Besar. Realita Jurnal Bimbingan dan Konseling Vol. 5 No 2 Edisi Oktober 2020. Hal 1051 - 1066. Prodi Bimbingan dan Konseling Fakultas Ilmu Pendidikan dan Psikologi Universitas Pendidikan Mandalika.

Arifin. 2011. Metode Penelitian. Jakarta: PT Bina Aksara
Arikunto dan Suharsimi.2006. MetodePenelitian. Bandung: Alfabete.

Budiman. 2002. Dasar-dasar Bimbingan dan Konseling. Jakarta: PT. Rineka Cipta.

Corey, G. 2005. Teori dan Praktek Konseling dan Psikoterapi. Bandung: PT Revika Aditama.

Depdiknas. 2002. Kamus Umum Bahasa Indonesia. Jakarta: Balai Pustaka.

Eisenberg, N., Guthrie, I.K., Cumberland, A., dkk. 2002. Prosocial Development in Early Adulthood: A Longitudinal Study. Journal of Personality and Social Psychology. Vol. 82.

Goege M. Gazda dalam Winkel. 1991. Bimbingan dan Konseling di Institusi Pendidikan. Jakarta: Gramedia

Hariadi Ahmad dan Aluh Hartati. 2016. Panduan Pelatihan Self Advocacy Siswa SMP untuk Konselor Sekolah. LPP Mandala. Mataram

Hariadi Ahmad dan Aluh Hartati. 2016.

Penerapan Teknik Structure

Learning Approach dalam

Meningkatkan Self Advocacy

Mahasiswa Prodi BK IKIP

Mataram. Realita Jurnal

Bimbingan dan Konseling Vol. 1

No 2 Edisi Oktober 2016. Hal 117

- 127. Prodi Bimbingan dan

Konseling Fakultas Ilmu

Pendidikan IKIP Mataram

Hariadi Ahmad dan Dini Kurnia. 2017.

Pengaruh Teknik Biblio Edukasi

Terhadap Rasa Rendah Diri Pada

Siswa Kelas XI di SMA Negeri 8

Mataram. Realita Jurnal

Bimbingan dan Konseling Vol. 2

No 1 Edisi April 2017. Hal 194 -

202. Prodi Bimbingan dan

Konseling Fakultas Ilmu

Pendidikan IKIP Mataram

Hariadi Ahmad, Ahmad Zainul Irfan dan Dedi Ahlufahmi. 2020. Hubungan antara Pola Asuh Orang Tua 
dengan Penyesuaian Diri Siswa. Realita Jurnal Bimbingan dan Konseling Vol. 5 No 1 Edisi April 2020. Hal 950 - 966. Prodi Bimbingan dan Konseling Fakultas Ilmu Pendidikan dan Psikologi Universitas Pendidikan Mandalika.

Hariadi Ahmad, Aluh Hartati dan Jessica Festy Maharani. 2020. Pengaruh Dukungan Psikologis Awal pada Remaja dalam Pencegahan Covid 19. Realita Jurnal Bimbingan dan Konseling Vol. 5 No 2 Edisi Oktober 2020. Hal 1091 - 1106. Prodi Bimbingan dan Konseling Fakultas Ilmu Pendidikan dan Psikologi Universitas Pendidikan Mandalika.

Hariadi Ahmad, Aluh Hartati, dan Nuraeni. 2018. Penerapan Teknik Structure Learning Approach (SLA) dalam Meningkatkan Kesadaran Empati Diri Siswa Madrasah Aliyah Al Badriyah. Realita Jurnal Bimbingan dan Konseling Vol. 3 No 2 Edisi Oktober 2018. Hal 600 - 605 Prodi Bimbingan dan Konseling Fakultas Ilmu Pendidikan IKIP Mataram.

Hariadi Ahmad, dan Lalu Andry Adifa Maulana. 2019. Pengaruh Teknik Video Edukasi Terhadap Berfikir Positif Siswa SMPN 16 Mataram. Realita Jurnal Bimbingan dan Konseling Vol. 4 No 1 Edisi April 2019. Hal 727 - 741. Prodi Bimbingan dan Konseling Fakultas Ilmu Pendidikan IKIP Mataram.

Hariadi Ahmad, dan Yolana Oktaviani. 2019. Pengaruh Teknik Self Instruction Terhadap Harga Diri Siswa Kelas Kelas XI di SMK Negeri 1 Lingsar Kabupaten Lombok Barat. Realita Jurnal Bimbingan dan Konseling Vol. 4 No 2 Edisi Oktober 2019. Hal 806
- 815. Prodi Bimbingan dan Konseling Fakultas Ilmu Pendidikan IKIP Mataram.

Hariadi Ahmad, Lidya Wurru dan Jessica Festy Maharani. 2021. Hubungan antara Keharmonisan Keluarga dengan Perilaku Agresif pada Siswa Madrasah Aliyah Raudlatusshibyan NW Belencong. Realita Jurnal Bimbingan dan Konseling Vol. 6 No 1 Edisi April 2021. Hal 1205 - 1212. Prodi Bimbingan dan Konseling Fakultas Ilmu Pendidikan dan Psikologi Universitas Pendidikan Mandalika.

Hariadi Ahmad, Mustakim dan Syafaruddin. 2018. Hubungan antara Penyesuaian Diri dengan Berfikir Positif Siswa Kelas VIII SMP Negeri Seteluk Kabupaten Sumbawa Barat. Realita Jurnal Bimbingan dan Konseling Vol. 3 No 1 Edisi April 2018. Hal 482 494. Prodi Bimbingan dan Konseling Fakultas Ilmu Pendidikan IKIP Mataram

Hasrul dan Hariadi Ahmad. 2021. Mereduksi Prasangka Etnik Siswa dengan Teknik Restructuing Cognitive Suatu Krangka Konseptual. Realita Jurnal Bimbingan dan Konseling Vol. 6 No 1 Edisi April 2021. Hal 1213 - 1222. Prodi Bimbingan dan Konseling Fakultas Ilmu Pendidikan dan Psikologi Universitas Pendidikan Mandalika.

Hutomono, S. (2011). Observasional Learning: Metode Psikologis Yang dilupakan dalam Psikologis Olahraga". Jurnal Ilmiah SPIRIT. $11,(2), 25-35$

Khomalasari, 2010 pembelajaran kontekstual. Bandung:PT Refika Aditama. 
https://e-journal.undikma.ac.id/index.php/realita

Lampert L. M. 2005. Modern Dairy Product 3rd Edition. Chemical Publishing. New York.

Margono. 2005. Bimbingan dan Konseling dalam Berbagai Latar Kehidupan. Bandung : Refika Aditama.

Neviyarni.2009. Pelayanan Bimbingan dan Konseling Berorientasi Khalifah Fil Ard. Bandung: Alfabeta

Paderson, Paul.B. 2008. Inclusive cultural empathy. First Edition. Washington: American Psichological Assosiation

Prayitno dan Amti. 2012. Pelayanan Bimbingan dan Konseling. Jakarta: Ikrar Mandiri Abadi.

Purwadarminto. 2003. Metodologi Penelitian. Jakarta: Aneka Cipta.

Sadmoko. 2010. Layanan Bimbingan dan Konseling. Padang: Universitas Negeri Padang.

Saraswati. 2008: Landasan Bimbingan dan Konseling. Bandung: Remaja Rosdakarya.

Sardiman.2011. Interaksi dan Motivasi Belajar Mengajar. Jakarta: PT Raja Grafindo Persada

Shaleh, A. R. (2004). Psikologi Suatu Pengantar dalam Prespektif Islam. Jakarta: Kencana.

Subana. dkk. 2005. Statistik Pendidikan. Bandung: CV. Pustaka Setia.

Sudirman N., dkk. 2002. Ilmu pendidikan. Remaja Rosda karya Rineka Cipta Bandung.

Sugiyono. 2013: Metode Penelitian Pendidikan (Pendekatan Kuantitatif,Kualitatif, dan $R \& D)$. Bandung: Alfabeta.

Sumadi Suryabrata. (2006). Psikologi Pendidikan. Jakarta: PT Raja Grafindo Persada.

Taufik.2012. Empati Pendekatan Psikologi Sosial. Jakarta: Raja Grafindo Persada. 


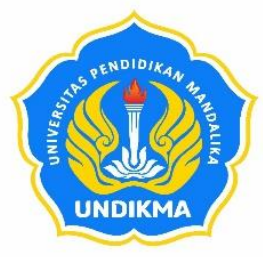

\section{UNIVERSITAS PENDIDIKAN MANDALIKA FAKULTAS ILMU PENDIDIKAN DAN PSIKOLOGI PROGRAM STUDI BIMBINGAN DAN KONSELING Jurnal Realita}

Gedung Dwitiya Lt.3. Jln Pemuda 59A Mataram-NTB 83125 Tlp (0370) 638991 e-mail: realita@undikma.ac.id; web: e-journal.undikma.ac.id

\section{PEDOMAN PENULISAN}

1. Naskah merupakan hasil penelitian, pengembangan atau kajian kepustakaan di bidang pendidikan, pengajaran, pembelajaran, bimbingan dan konseling, dan Psikologi

2. Naskah merupakan tulisan asli penulis dan belum pernah dipublikasikan sebelumnya dalam jurnal ilmiah lain,

3. Naskah dapat ditulis dalam Bahasa Indonesia atau Bahasa Inggris.

4. Penulisan naskah mengikuti ketentuan sebagai berikut:

$\begin{array}{llll}\text { Program } & \text { MS Word } & \text { Margin kiri } & 3.17 \mathrm{~cm} \\ \text { Font } & \text { Times New Roman } & \text { Margin kanan } & 3.17 \mathrm{~cm} \\ \text { Size } & 12 & \text { Margin atas } & 2.54 \mathrm{~cm} \\ \text { Spasi } & 1.0 & \text { Margin bawah } & 2.54 \mathrm{~cm} \\ \text { Ukuran kertas } & \text { A4 } & \text { Maksimum 20 halaman }\end{array}$

5. Naskah ditulis dengan sistematika sebagai berikut: Judul (huruf biasa dan dicetak tebal), nama-nama penulis (tanpa gelar akademis), instansi penulis (program studi, jurusan, universitas), email dan nomor telpon penulis, abstrak, kata kunci, pendahuluan (tanpa sub-judul), metode penelitian (tanpa sub-judul), hasil dan pembahasan, simpulan dan saran (tanpa sub-judul), dan daftar pustaka.

Judul secara ringkas dan jelas menggambarkan isi tulisan dan ditulis dalam huruf kapital. Keterangan tulisan berupa hasil penelitian dari sumber dana tertentu dapat dibuat dalam bentuk catatan kaki. Fotocopy halaman pengesahan laporan penelitian tersebut harus dilampirkan pada draf artikel.

Nama-nama penulis ditulis lengkap tanpa gelar akademis.

Alamat instansi penulis ditulis lengkap berupa nama sekolah atau program studi, nama jurusan dan nama perguruan tinggi. Penulis yang tidak berafiliasi pada sekolah atau perguruan tinggi dapat menyertakan alamat surat elektronik dan nomor telpon.

Abstrak ditulis dalam 2 (dua) bahasa: Bahasa Inggris dan Bahasa Indonesia. Naskah berbahasa Inggris didahului abstrak berbahasa Indonesia. Naskah berbahasa Indonesia didahului abstrak berbahasa Inggris. Panjang abstrak tidak lebih dari 200 kata. Jika diperlukan, tim redaksi dapat menyediakan bantuan penerjemahan abstrak kedalam bahasa Inggris.

Kata kunci (key words) dalam bahasa yang sesuai dengan bahasa yang dipergunakan dalam naskah tulisan dan berisi 3-5 kata yang benar-benar dipergunakan dalam naskah tulisan.

Daftar Pustaka ditulis dengan berpedoman pada Pedoman Penulisan Karya Ilmiah Universitas Pendidikan Mandalika. 


\begin{tabular}{|c|c|c|c|c|c|}
\hline & & & & \\
JURNAL & VOLUME & NOMOR & EDISI & HALAMAN & P ISSN : 2503 - 1708 \\
REALITA & 6 & 2 & Oktober 2021 & $1326-1430$ & E ISSN : 2722 - 7340 \\
& & & & \\
\hline
\end{tabular}

Alamat Qedaksi:

Program Studi Bimbingan dan Konseling Fakultas Ilmu Pendidikan dan Psikologi

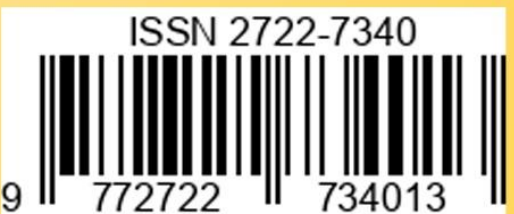

Universitas Pendidikan Mandalika

Gedung Dwitiya, Lt. 3 Jalan Pemuda No. 59A Mataram Telp. (0370) 638991

Email : realita@undikma.ac.id

Web : e-journal.undikma.ac.id

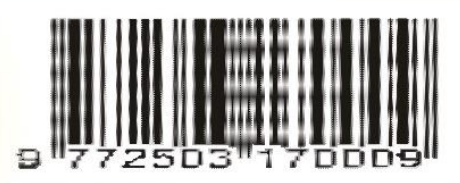

